\title{
Early Symptoms of Modernism in Traditional Balinese Painting Began in Northern Bali
}

\author{
I Dewa Alit Dwija Putra ${ }^{1}$, Sarena Abdullah ${ }^{2}$ \\ ${ }^{1}$ School of Creative Industries, Telkom University, INDONESIA \\ ${ }^{2}$ School of the Arts, Universiti Sains Malaysia, MALAYSIA \\ Authors' email: 'dwijaputra@telkomuniversity.ac.id; ${ }^{2}$ sarena.abdullah@gmail.com
}

Published: 28 September 2020

\begin{abstract}
The history of significant changes in traditional Balinese art towards modern art took place in the 1930s in the village of Ubud, South Bali. Visual changes in Balinese art are unlike changes in modern art in the West or in Indonesian modern art. The visuals show a strong traditional style, although signs of modernity as this paper will argue, can be found. Modern Balinese art in Ubud in the 1930s actually started in North Bali in the 1870s. It was the role of two Dutchmen named Van der Tuuk and W.O.J. Nieuwenkamp, a linguist and academic artist, who contributed to the introduction of modern art to North Balinese artists. The interaction between the two Dutchmen and the local artists gave birth to arts that are slightly different from traditional arts in Bali. This paper will discuss the shift from traditional to modern painting done by Balinese artists in this early period that resulted in the transition of traditional to modern art through the changes in techniques and media; and themes and functions of these visuals. As such, this marks a shift from art that are no longer spiritual but lean more towards the profane.
\end{abstract}

Keywords: painting, modern, North Bali

eISSN: 2550-214X @ 2020. The Authors. Published for Idealogy Journal by UiTM Press. This is an Open Access article distributed under the terms of the Creative Commons Attribution-NonCommercial-NoDerivatives License (http://creativecommons.org/licenses/by-nc-nd/4.0/), which permits non-commercial re-use, distribution, and reproduction in any medium, provided the original work is properly cited, and is not altered, transformed, or built upon in any way.

\section{INTRODUCTION}

The island of Bali is part of the central Indonesian archipelago. Known as the "Island of the Gods", the island of Bali has many "temples" or places of worship for the Hindus of Bali. Geographically, Bali is divided into two regions, South Bali and North Bali, which are separated by mountain ranges stretching from west to east with a peak called Mount Agung. South and North Bali have different characteristics with regard to society; the North Balinese are more egalitarian and open, unlike society from South Bali which is more closed and still holds many feudalistic values.

North Bali has an earlier historical civilization than South Bali. The centre of the first kingdom was in Singhamandawa, North Bali (Ardika, Parimartha, Wirawan. 2015: 107). Thus, contact with foreign cultures and foreigners also first occurred in North Bali. This condition is supported by the presence of large ports along the coast of North Bali, as it is a strategic area for global trade routes and spice routes in the eastern region of the Indonesian archipelago.

During this time, historians in the history of Balinese art mentioned the milestone of the radical transformation of Balinese traditional painting to modern painting that was marked by the establishment of an art organization called Pita Maha in 1935. Pita Maha, was pioneered by two European artists, namely, Walter Spies and Rudolf Bonnet, and was supported by Puri Ubud Royal- Cokorda Gede Raka Sukawati and his younger brother Cokorde Gede Agung Sukawati. This organization was established as a forum for Balinese artists to gather, study and learn more about modern art (Neka, Kam, 1998: 19).

This art organization developed and gave birth to three streams of style in new or modern Balinese painting. The three art genres were named according to the environment, and the community of artists 
and their activities. They interact with each other, both with artists in their village and other village artists. This involved mutually imitating each other and due to the development of styles by individual artists, works that have similarities or portray the region were created. That gave birth to three styles in accordance to the names of the regions, namely, Ubud style, Batuan style and Sanur style. At the same time, traditional Balinese puppet painting still continues.

After North Bali was controlled by the Dutch in 1849 through the Jagaraga war, the centre of colonial government and economy was located at Singaraja Buleleng, North Bali. Since then, many foreigners have arrived, especially European scientists and artists who visited Bali. European immigrants and tourists are basically interested in the nature and culture of Bali, especially information about the ritual called mesatya which involves the sacrifice of a wife or empress and their concubines when the king dies in war (Warsika, 2017: 141).

The arrival of Europeans, especially the Dutch to Bali, as scientists, was a separate mission from the colonial government to learn and understand Balinese society and culture as well as to learn how the colonial government could control the whole of Bali and gain economic control through trade which is still controlled by several kingdoms in Bali. The scientists sent to Bali were widely spread around and blended in with the lower classes of society as part of an effort for their research to look deeper into the lives of Balinese people.

Two Dutchmen, Van der Tuuk and W.O.J. Nieuwenkamp, who came to Bali although they did not come together at the same time, brought changes to the conventions of Balinese artists in their artistic practices. Van der Tuuk was a linguist sent by the Dutch kingdom, while W.O.J. Nieuwenkamp was an adventurist with a background in art. W.O.J. Nieuwenkamp liked to create drawings and paintings about Balinese nature and culture while traveling from one place to another. These activities were carried out at the island of Lombok. During these activities, there was an indirect interaction with the community and Balinese artists with regard to the practice of modern art. The way Nieuwenkam worked was easy to imitate by Balinese artists, because Balinese people are known to be reliable imitators.

In a book written by Hinzler (1986: 4), a picture dictionary project that was produced by Van der Tuuk describes the artistic works of fourteen artists from various places in the Bali region. Nine of them came from North Bali. The rest are believed to be from South Bali, specifically around the Tabanan and Badung areas. In the making of the Balinese-Kawi-Dutch dictionary, the Balinese artists were given paper, watercolours and other drawing equipment. Van der Tuuk tried to give media stimuli to Balinese artists to make drawings according to their artistic conventions. Images could be annotated with writings to clarify what was made. While completing the three-language dictionary project, hundreds of images of "wayang" and shadow puppets from North Balinese artists were successfully collected.

Artist W.O.J. Nieuwenkamp (1874-1950) was the first Dutch person to make prints and drawings of Bali for Western audiences. He came to Bali in 1903. Before going to Bali, Nieuwenkamp studied Balinese paintings collected by Van der Tuuk. Nieuwenkamp imitated and studied the paintings made by I Ketut Gede from Sawan. After his arrival in North Bali, he met with Ketut Gede, and he then travelled to southern Bali, where he met with Kamasan artists and collected their works. Besides Bali, he also visited the island of Lombok. Due to the fact that he was happy with the nature and culture of Bali, he repeatedly came to Bali and witnessed the birth of New Balinese art (Modern Balinese Art) in 1937 (Vicker, 2012: 336).

The role of two Dutchmen in North Bali brought changes to traditional Balinese puppet painting. The technological advances introduced by them, such as paper, watercolour, oil paint and canvas, encouraged the acceleration of Balinese artists' work. Paper and cloth made it easier for Balinese artists to create paintings that were previously done on coarse cloth and bark. Paper was used to create pictures like portrait drawings. With just one puppet figure on one sheet of paper, the narrative characteristic of traditional painting was eliminated. This one scene marks the beginning of the change in traditional Balinese painting. 
This study looks at the extent of the changes or adaptations of modern art practices in traditional Balinese painting due to the modern influences brought by two Dutchmen --Van der Tuuk and W.O.J. Nieuwenkamp. Modern characteristics that are shown in traditional puppet painting that will be discussed in this paper can be seen in the themes, composition, techniques and media, and the change in the function of the painting itself. What themes or styles were adopted by Balinese artists so that the paintings made are different from traditional paintings? What are the modern characteristics that can be observed in these works? How have these works changed in terms of function?

\section{RESEARCH METHODS}

This paper discusses several selected traditional Balinese artworks through observation, interviews, literature studies and visual analysis. These qualitative methods, according to Bogdan and Taylor in Ratna (2016: 95), do not merely describe the data but more importantly, could help us in finding the meaning behind the artworks as there may be a hidden meaning that cannot be deciphered by quantitative methods.

This paper will explore and discuss the historical and social background of the people of North Bali behind the physical appearance of art objects, which in this case are traditional paintings. The background of these traditional paintings can be obtained through literature study, and various documentations in the Museum of North Bali Buleleng related to the development of the early history of art; the characteristics of the people of North Bali; the colonialism period; and the adaptation of the people of North Bali to the influences of foreigners or foreign cultures entering Bali.

The discussion in this paper was done by referring to several Van der Tuuk collections from a catalogue produced by Hinzler. Some visual examples that will be discussed here as the main studies are works that show and denote these visual changes. Then, these works are discussed in the context of the practices and properties of modern art by focusing on the extent or how far modern influences have been adapted into traditional Balinese puppet painting.

Research into this historical background requires artefact data as research subjects. The artefacts are in the form of art objects, namely, paintings and drawings. The paintings that were selected in this study are traditional puppet paintings which were the result of the work of Balinese artists involved in the Balinese-Dutch dictionary project undertaken by Van der Tuuk. Some of these works can be seen in the Buleleng Museum at Singaraja, North Bali.

\section{TRADITIONAL BALINESE PAINTING}

Traditional Balinese puppet painting is also known as Kamasan classical puppet art; the term "classic" is often used as a reminder that this art has its roots in classical Hindu heritage during the reign of Dalem Waturenggong, which was around since 1460-1550 AD and when Balinese art was in its heyday or at its golden peak. This classic art is the basis or a benchmark of traditional art in Balinese society until now. The word "classic" denotes a convention of rules that have been developed from generation to generation, both in the process and its performance (Irfansyah, 2013: 206, Putra, 2019: 131).

The word "Kamasan" refers to a village in Klungkung where the art of puppet painting is still being practiced, both for religious ceremonies and to create handicraft products. The Balinese are more familiar with the Kamasan puppet as a traditional painting than in other forms. Thus, traditional Balinese puppet painting is attached to the word Kamasan, even though puppet painting activities in Bali can be found in all regions in Bali, all with their own respective characteristics (Vicker, 2011: 14).

Puppet imagery can be traced on lontar prasi which is a type of comic illustration made on the palm leaf of 'tal,' a type of palm tree. This comic illustration is made by making incisions using a small knife made specifically for this purpose (temutik), then rubbing the incisions with ink made from hazelnut 
oil. Lontar prasi is used to illustrate a story called Mahabharata and Ramayana, which was popular in Bali, as well as a fable called Dyah Tantri. Other than entertainment purposes, classic puppet imagery can be seen on long cloths positioned at the edge of the roofs of bale-bale buildings and mounted for a religious ritual called pengider-ider in temples. Puppet paintings are called parba, which serve as a backdrop to the stories of mythological deities and religious symbols, and are mounted behind beds (bale). Traditional calendars (palelintangan) are also usually installed behind beds. Palelintangan is used to determine the merits of the day. The images usually used are classic religious ritual instruments called kober or lelonte or banners, which are a type of cloth that extends upward on bamboo poles (Adnyana, 2018: 74).

Classical puppet paintings can be found on langse, a type of mosquito curtain on bale-bale or Balinese houses. The forms of traditional puppet figures can also be found on the walls (penyengker) of temples in the form of relief carvings combined with traditional ornaments. The pictures were considered mystical and to have supernatural powers - these pictures are usually drawn on specific media such as palm leaves, cloth, pottery, bricks and tattoos. In rajahan (figural) form, puppet figures usually illustrate astral beings with Balinese or Javanese ancient writings that contain certain spells.

Regarding the iconography of puppet painting figures, it actually refers to the puppet performance art (shadow puppet), where these forms have similarities to the depictions of figures in the reliefs of East Java during Majapahit's reign. The close relationship between the puppet form in the relief and the puppet form in Bali, considering that Bali was once conquered by Majapahit, means that all aspects of life use Majapahit's rules. When Majapahit collapsed due to the strong emergence of Islamic empires in Java, remnants of Majapahit culture were left behind in Bali ((Yudoseputro, 2008: 124) in (Putra, 2019: 133)).

Historically, Balinese modern art was part of the development of Indonesian modern art. However, Balinese modern art is often identified as a form of development that has its own plot, which is different from other fine arts or modern art in Indonesia. Balinese art had a rather separate development that occurred around 1930. Modern Balinese art uses more traditional sources, but is no longer intended for rituals as it is now an economic commodity (Lombard, 1996: 182).

Sudarta (1975: 27) revealed that the current painting style is modern Balinese painting which is an evolutionary development of the Kamasan puppet painting style, as it has developed into a more realistic style in terms of theme, colour and technique. It seems that Balinese painting has now found its form or has reached the highest quality, which is difficult to be swayed by the influence of modern painting

The characteristics of modern art such as novelty, innovation, rationality and individuality seem to have been introduced to Balinese artists. However, the awareness about this in Balinese artists has not yet been identified (Jim Supangkat, 1996: 52). This is because Balinese society does not have the concept of "art" and "artist". Art is the property of its people, and art serves the interests of religion and ceremonies.

\section{THE ROLE OF TWO DUTCHMEN}

North Bali yielded to the Netherlands in 1849 through the Jagaraga war. The people of North Bali (Buleleng), led by I Gusti Ketut Jelantik, carried out Puputan which was an all-out war, which resulted in the defeat of Buleleng. After the defeat, the North Bali government was automatically handed over to the Dutch colonial power. During the reign of the Dutch East Indies government, many European scientists and writers were sent to study Balinese culture. Even European academics and artists followed suit and went as far as even residing in Bali.

Introductions of Balinese people to modern imageries had already occurred long before Bali was conquered by the Dutch. Around 1579, the first Dutch envoy to arrive in Bali was named Cornelis de Houtman. One of de Houtman's messengers met with the king of Bali and showed him a map or the 
visual of a Dutch territory. In addition, the Balinese, especially the North Balinese, were accustomed with images carried by Chinese traders. Bear in mind that North Bali is a coastal area and has large ports such as Sangsit and Buleleng. Before the arrival of European or Dutch traders, North Bali was controlled by Chinese, Mandar and Bugis traders. They traded as far as the interior of North Bali, so the Balinese knew about illustrated paper money, porcelain and ceramics from Chinese traders, and colouring materials such as ginju (red ink obtained from the merchant). The influence of Chinese cultural elements on traditional Balinese painting has also triggered changes in themes and richer aesthetic expressions.

The Dutch scientist who was very instrumental in changing Balinese traditional painting was Herman Neubronner Van der Tuuk, a language scientist and anthropologist who succeeded in creating a Javanese-Dutch dictionary. He was born in Malacca in 1824, right when the Dutch were going to hand over Malacca to the British. Van der Tuuk grew up in Surabaya, East Java, and began living in Bali from 1870 onwards until he died in a hospital in Surabaya in 1894. Smart and well-educated, Van der Tuuk rarely spent time socializing and was seen as eccentric by his fellow Dutch friends. Van der Tuuk adopted Balinese attire and a Balinese lifestyle, and used to go barefooted around the beach during the day wearing pyjama pants and native clothes without a hat, while carrying rough and heavy batons (Vicker, 1989: 83).

Hendrik Neubronner van der Tuuk was originally appointed by the Dutch Bible Society to collect data for the Balinese-Dutch dictionary project. To make the dictionary project more complete, Van der Tuuk wanted to add visual materials to his dictionary. He had done this kind of project before for Toba Batak in North Sumatra. While collecting words, Van der Tuuk involved several Balinese artists so that the pictures could be illustrated with information in Balinese script to provide visuals of important situations, ideas or objects. Fourteen Balinese artists were selected and involved in producing the dictionary; as mentioned in the early part of this paper, ten were from North Bali, while the rest were from Badung and Tabanan. Most of the people who helped in the making of the dictionary drawings were nameless and even their villages were not mentioned. There are only three people with names written on the picture, namely, Ida Putu Hema from Griya Pratoda, Badung; Ida Made Griya Tlaga from Sanur, South Bali; and the third, I Ketut Gede from Griya Sawan Buleleng, North Bali. The name I Ketut Gede is known thanks to the notes from W.O.J. Nieuwenkamp (Hinzler, 1986: 3).

Van der Tuuk did not come to Bali alone; he was accompanied by F.A. Liefrinck, and they arrived in Bali around 1870. Both of them focused their research on Balinese culture. They arrived in Bali when northern Bali had become a Dutch power with the first Dutch bureaucrat in Singaraja named P. van Bloemen beginning to reorganize the North Bali government. Both Liefrinck and Van der Tuuk continued their interest in accumulating and documenting knowledge about the life and culture of the Balinese, a practice that was first initiated by Baron van Hoevell in 1840 and Raffles at the beginning of the century. Their investigation included a deeper search for people in the Indies, scientifically, with the idealistic goal of helping indigenous people through welfare policies by the colonial government. Van der Tuuk and Lienfrinck contributed to the new perspective on Bali, especially in terms of its culture in the Indies community (Vickers: 1989: 83).

Van der Tuuk has broad insight not only on European classical literature, but also Indian literature and mystery novels. Like Raffles and Friederich, Van der Tuuk thought that the Brahmins were the real source of information and cultural carriers. He compared the Balinese to the Bataks in Sumatra, where he had lived before, and concluded that "so far the Balinese make me happier than the Batak people". But he did not mean all the Balinese; only the priestly castes he regarded as fellow scholars. "The Brahmins here are highly cultured and friendly in character. It is unfortunate that the government does not pay attention to them, let alone our civil servants ignore the savagery of the king" (Vicker, 1989: 84).

W.O.J. Nieuwenkamp was born in Amsterdam in 1874, and died on 23 April 1950 in San Domico di Fiessole in Italy. He was a Dutch painter, wood carver, graphic artist, illustrator and collector. He also created many books and paintings of the nature and culture of Bali and the island of Lombok. 
Nieuwenkamp was the person who visited Bali most often in 1904,1906, 1916-1917 and 1935-1937 (Hinzler, 2013). He had witnessed the birth of the Balinese modern art movement and the Pita Maha organization. During his arrival in 1906, Nieuwenkamp was surprised to see himself depicted cycling on one of the reliefs at Pura Madue Karang in the village of Kubutambah North Bali (Adnyana, 2018: 15).

Nieuwenkamp's relationship with Balinese artists was very brief, and there was no exchange of ideas, and no introduction to new ways of drawing, painting or carving. He was very impressed by the way Balinese artists made paintings and sculptures, which he obtained from the Van der Tuuk Collection. Nieuwekamp then learned and was influenced by Balinese drawings. His paintings have similarities with Balinese paintings and many were published in his book Bali en Lombok.

Nieuwenkamp was the first Westerner to produce Balinese prints and other drawings for Western audiences. He studied the work of Ketut Gede in the Netherlands before going to Bali in 1903, and then met with Ketut Gede and the artist who helped Van der Tuuk with his dictionary. Nieuwenkamp then went to southern Bali, where he met with Kamasan artists and collected their works, and imitated some of their paintings. He continued to visit Bali until 1937, and thus could also witness the birth of a modern art style on the island (Vicker, 2012: 336).

There was interaction between the two Dutchmen and Balinese artists, albeit in a different way. Van der Tuuk interacted with Balinese artists by way of inviting them to his residence. Meanwhile Nieuwenkamp interacted whilst he travelled around by bicycle, riding horses on even when he went for a walk to paint and draw the panoramaas and the Balinese people that he encountered. The interaction with the artists by Van der Tuuk was more on his introduction to techniques and media commonly used in Europe, such as paper, watercolours, inks and pens. The introduction of media and watercolour techniques seem to have provided a new experience for the Balinese artists. Balinese artists, in the making of traditional images, usually use natural colouring materials. The use of paper media in small sizes limits Balinese artists in making narrative puppet paintings.

How was the introduction of modern art carried out by Nieuwenkamp? He often went around and made paintings of objects that he saw both in nature and in people's homes. Indirectly, what was done was imitated by Balinese artists, because the Balinese are basically reliable imitators. Imitators in the sense that not all of what is imitated must be similar or the same but there are aspects for interpretation that give birth to work with a personal style.

Direct and indirect interactions indicate that the attitude of North Balinese artists was very open to new ideas outside of their religious life as Balinese people. This open attitude also became an important foundation for dialogue between the two cultural elements brought by foreigners and the Balinese artists. The interaction and adaptation of cultural elements will be seen in the paintings made. The signs of visual changes in classical Balinese puppet painting will be described in the next discussion.

\section{EARLY SYMPTOMS CHANGES IN TRADITIONAL PAINTING TOWARDS MODERN ART IN NORTH BALI}

What is meant by signs of these modern elements in traditional Balinese painting, is the existence or the use of methods or techniques that are commonly used in making drawings and paintings in modern (Western) art. Does the painting have modern characteristics that refer to aesthetic problems (autonomous art) and style? These signs are traced from works produced by these fourteen Balinese artists who assisted Van der Tuuk in the making of his visual dictionary. Some selected works discussed here are able to present and show modern changes such as themes, styles, compositions and others.

As also revealed by Vicker (2012: 122), the singular form or portrayal of the puppet or figure itself is made on a piece of paper. In the context of traditional painting, this is never done. The creation of a puppet painting always consists of several figures or characters in one story scene. The painting was made up of several scenes that continued so that the narration of the story remains intact (See Table 1). 
Table 1: Traditional Balinese wayang painting

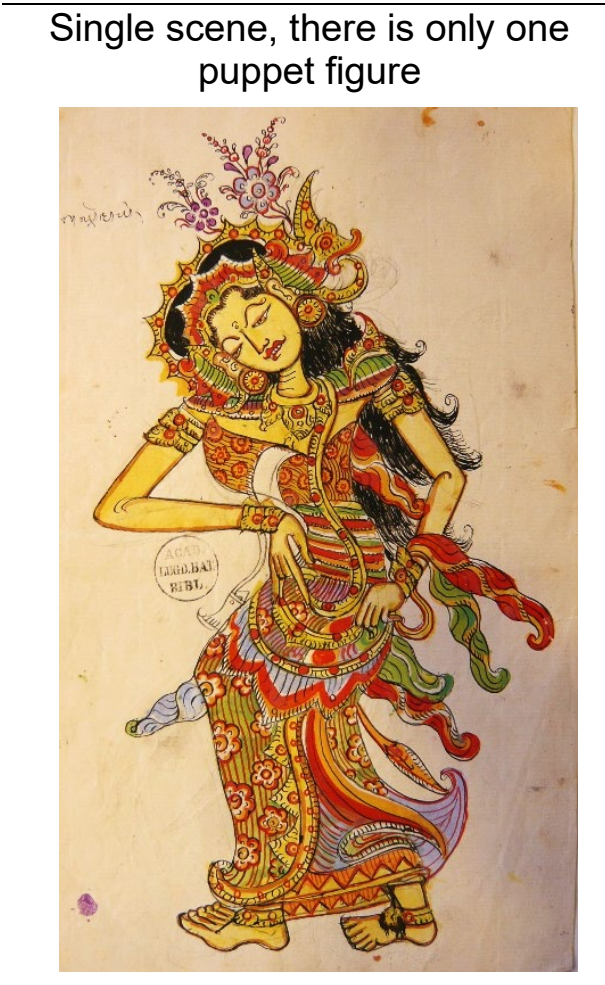
One panel, there are several stories to connect, read from the bottom up

Source : Hinzler, 1987: Or.3390232

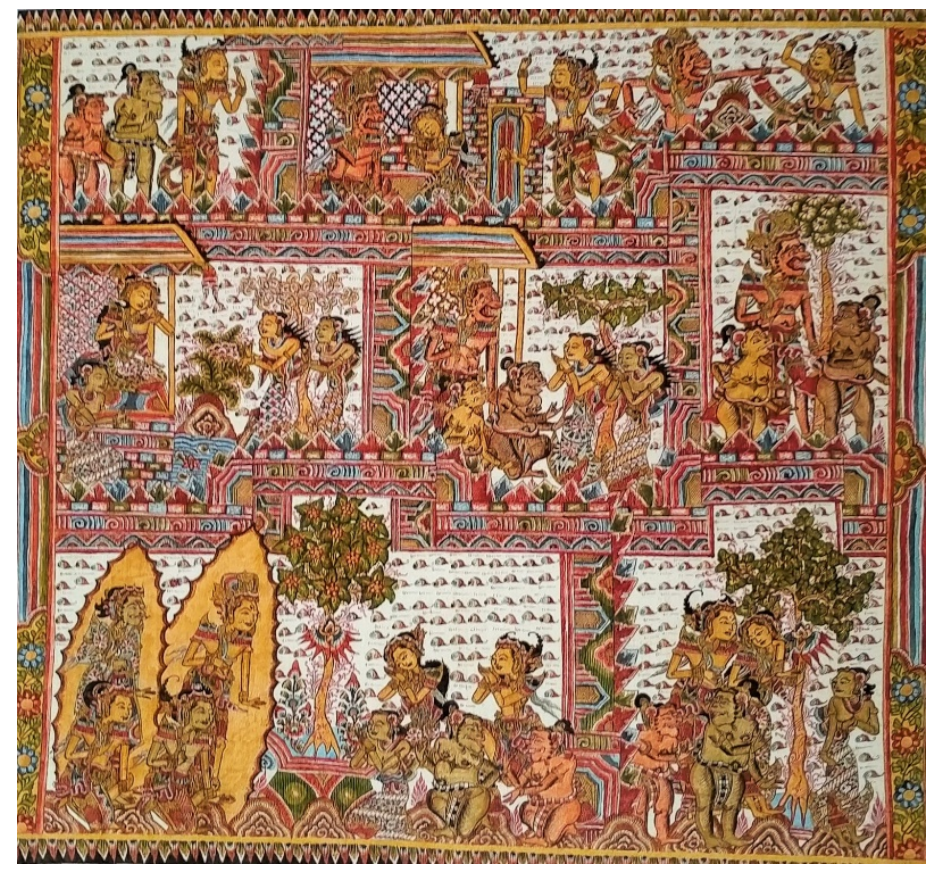

Source: Vicker, 2014: 24

There are also thematic changes and shifts in traditional Balinese wayang painting. Usually, Balinese traditional wayang paintings use story themes from elements of Hindu-Indian culture, such as Mahabharata and Ramayana, in addition to Balinese folklore and legends such as Calonarang, Panji and Cupak-Grantang, and popular fable stories by Dyah Tantri. Thematic shifts using or highlighting the theme of everyday life has become a source of ideas for painting. This is an interesting thing to note, as artists had begun to make recordings of what happened in the social life of the community at that time. Trade events, lively religious ceremonies, dances, and not infrequently, Balinese artists also recorded Dutch colonial life in Bali.

The characteristics of the North Bali region as a multicultural area is also reflected in the work made by I Ketut Gede, the artist who had worked with Van der Tuuk the longest. His painting shows two Chinese figures watching a ritual offering to demons (butha) called mecaru. The ritual offerings are placed on a woven square of bamboo. There is a person holding a machete to cut a black chicken as a complement to the ceremony. In the middle of the painting, there is a figure of a Muslim reading a book and three people who are listening. The painting depicts the existence of activities the Chinese people and Muslims had interacted with in the life of the local community. The Chinese, and Muslims such as the Mandar and Bugis were the economic (trading) rulers in North Bali at the time. I Ketut Gede and other North Balinese artists were very explorative in responding to environmental situations, which were used as the theme of paintings. This condition was very different from before the arrival of the two Dutch scientists (see Figure 1). 


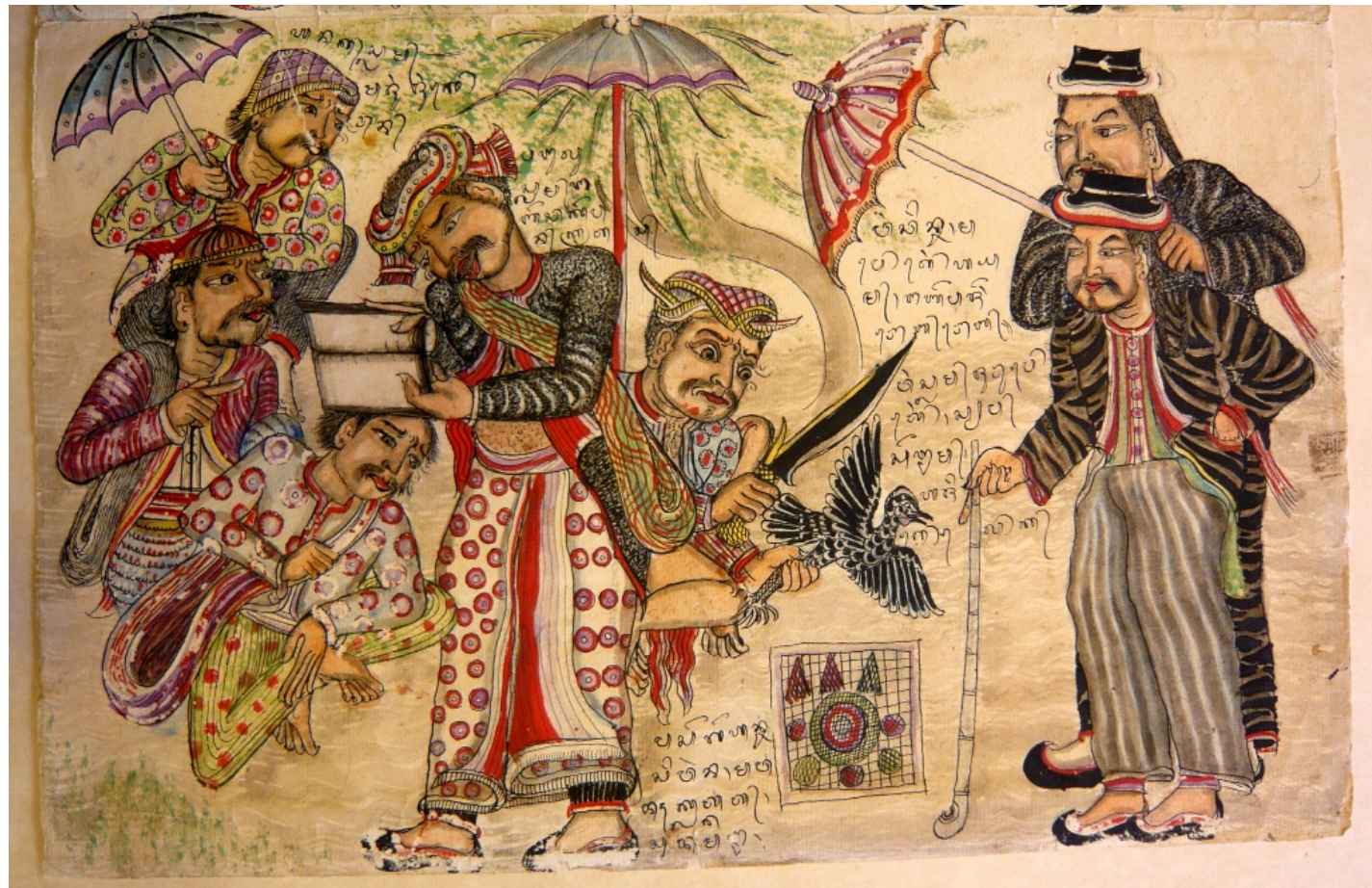

Figure 1: Themes about daily life including ethnic diversity became a source of new ideas for North Balinese artists

Source: Hinzler, 1987: Or.3390: 256b

Traditional Balinese puppet paintings with distilled forms with black contour lines made with a pen display a strong decorative and ornamental aspect. When Balinese artists were introduced to watercolour techniques, they got new experiences with the watercolour medium. Watercolour practice was applied in puppet painting, creating a combination of two deep techniques in puppet painting. The watercolour technique of expressive brush strokes was imitated and applied to puppet paintings, especially in painting leaves and the sky. The combination of techniques caused the decorative aspects of the leaves and sky to change slightly towards realism (see Figure 2). The technique of making leaf covers like this is still being done in the puppet painting on glass practice in Nagasepaha Village, Buleleng. The habit of making trees and leaf covers was influenced by the European style of painting in the 19th century which depicted objects of scenery, whereas in Indonesia, especially in Java, it was called the mooi indi style in the early 20th century (Burham, 2013). 


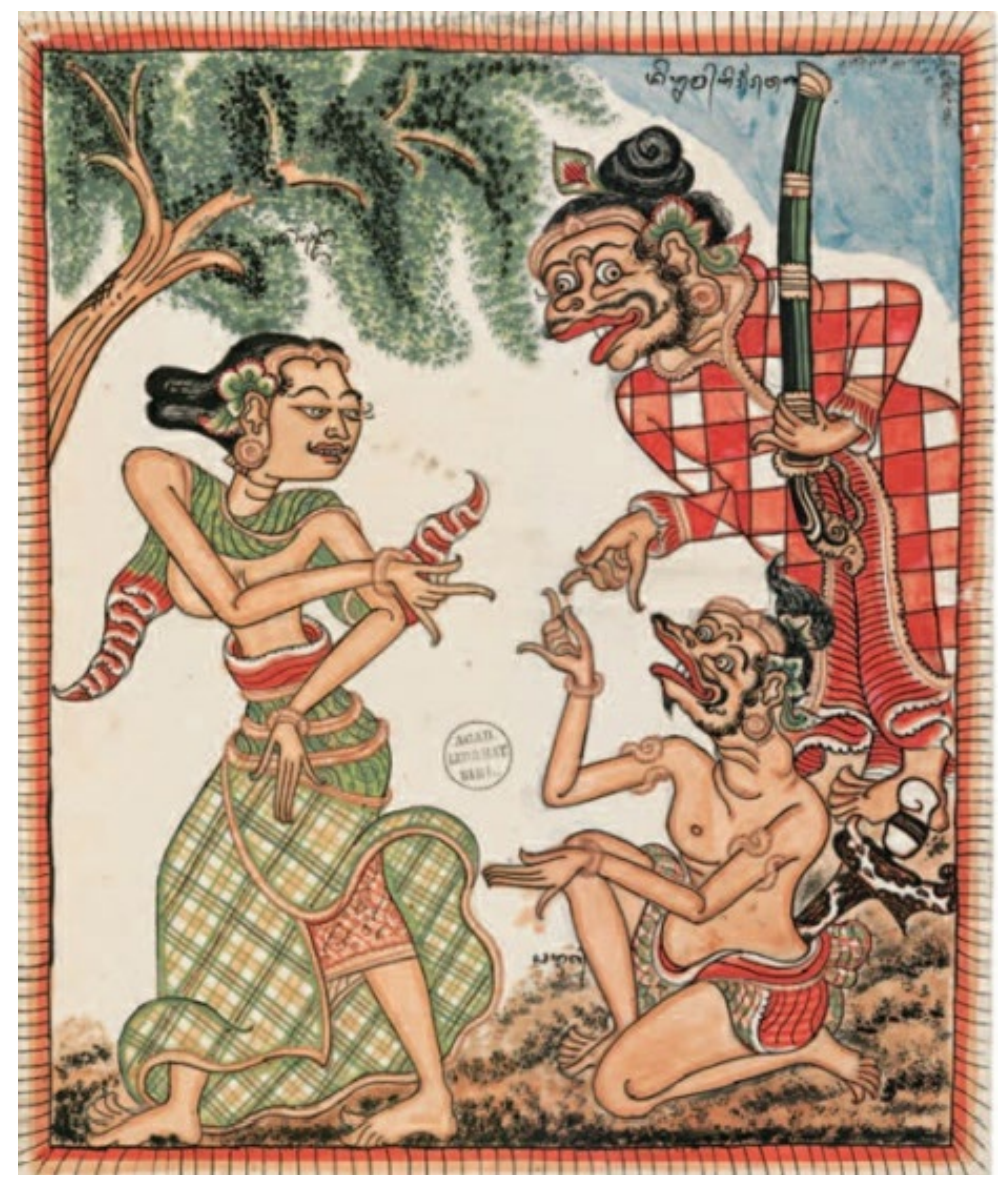

Figure 2: The technique of painting leaves and sky is influenced by European and "Mooi Indi" landscape painting styles in Indonesia Source: Hinzler, 1987

In some of Van der Tuuk's collections, the works of Balinese artists still show their strong traditional wayang painting styles although there have been changes in themes and techniques. They are also unique and distinctive in terms of the combination of figures in these puppet paintings and the new figures created by these Balinese artists. As an example, a painting made by Putu Hema shows that the figure of Arjuna is a figure from the Mahabharata epic combined with several foreign figures.

The painting (see Figure 3) shows that on the left, there is a figure wearing a black cone-shaped headgear tapering upwards, which is called apit surang. The attribute indicates that Arjuna is the central figure in the Mahabharata story. Arjuna is shown with one of his hands held straight ahead with open fingers as if signaling someone to stop what they were doing, while the other hand is raised upward. In front of Arjuna at the bottom, there are three figures, namely, a bearded male figure wearing a hat, who is holding the chest of one of the two female figures who are sitting on their knees. The two forms of female figures with such attributes are symbols of palace maids. The scene in the painting tells how Arjuna tried to stop the indecent acts committed by strangers against palace maids.

On the right side of the painting, there are three male figures, who are standing under the roof of the house (bale-bale). One of the figures is wearing a hat similar to that worn by the figure holding the servant's chest. The other two figures are wearing hats and clothes, and have slanted eyes. The shape of the narrow eyes usually denotes a Chinese person. Thus, these figures are foreigners, namely, two Europeans (Dutch) and the other two Chinese. The appearance of foreign figures in puppet painting was a new thing that had never been done before. This shows changes in the Balinese artists who broke away from the grip of traditional art. The existence of individual freedom is a feature of modern art. 


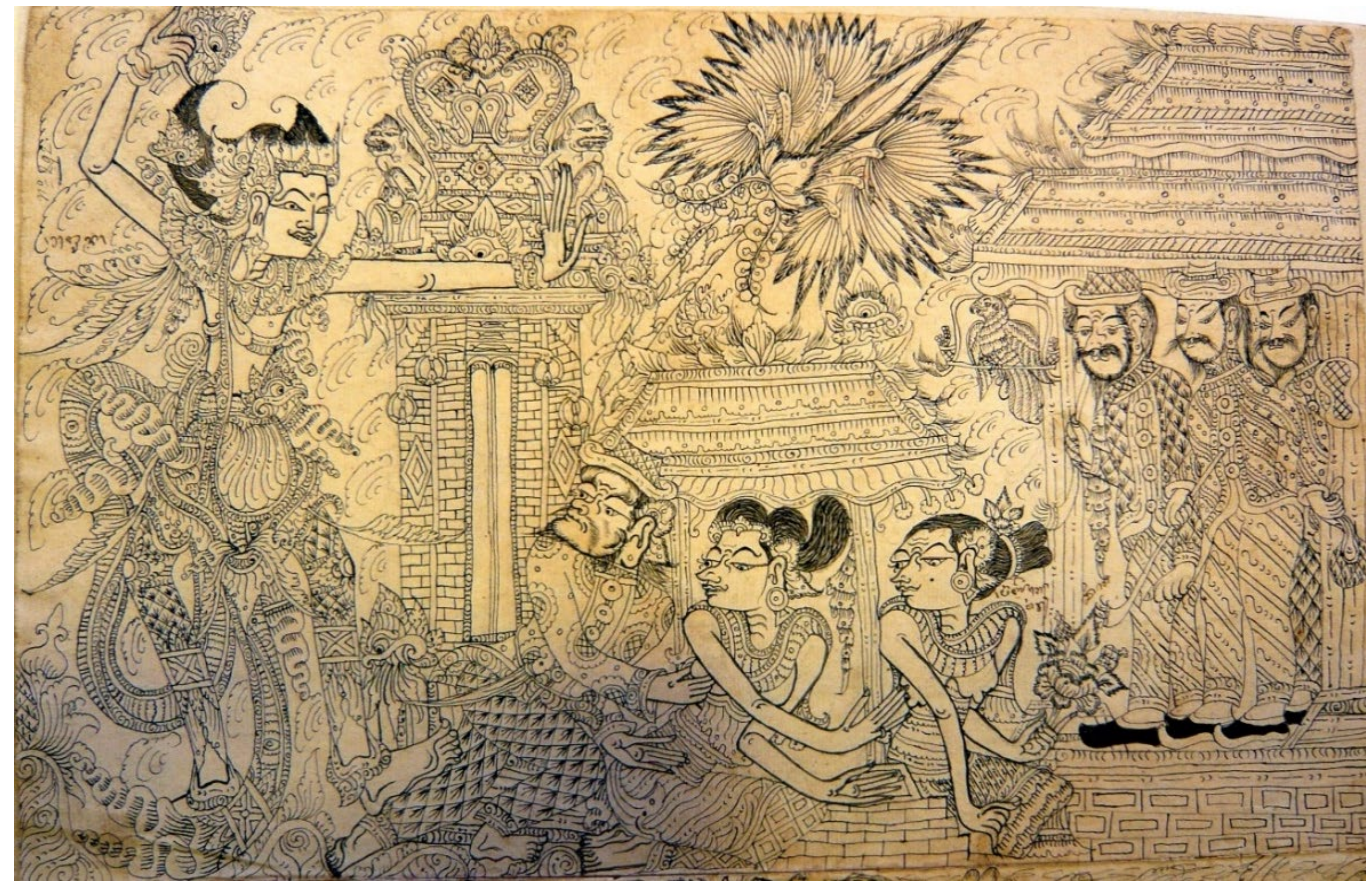

Figure 3: Balinese artists enter new figures (2 Chinese and 2 Dutch) in their traditional paintings.

Source: Hinzler, 1987.

Of the fourteen Balinese artists who were members of the Balinese-Dutch dictionary project by Van der Tuuk, three had signed on the paintings. The artists were Ketut Gede from Griya Sawan Buleleng, Ida Made Telaga from Sanur, and Ida Putu Hema from Badung. This shows that Balinese artists had begun to follow the ways of European artists in the sense that the outcome of works of art has become personalized. This is in contrast to the traditional understanding of Balinese painting, which is seen as the property and expression of its people. Individual signatureshowever, indicate a personal approach or style rather than a collective outcome (Adnyana, 2018: 13).

In addition, there were efforts by Balinese artists to explore techniques such as those of European artists who were painting with watercolour techniques. Balinese artists no longer use sketches with pencils or pens. As a result, they tried to directly apply watercolour and ink techniques in making drawings and paintings while still using puppets as the subject matter. The Balinese artists made an effort to create paintings that are more expressive than previous decorative paintings, resulting in a difference between the art of puppet painting in north Bali and southern Bali, which are more orderly and patterned (see Figure 4). 


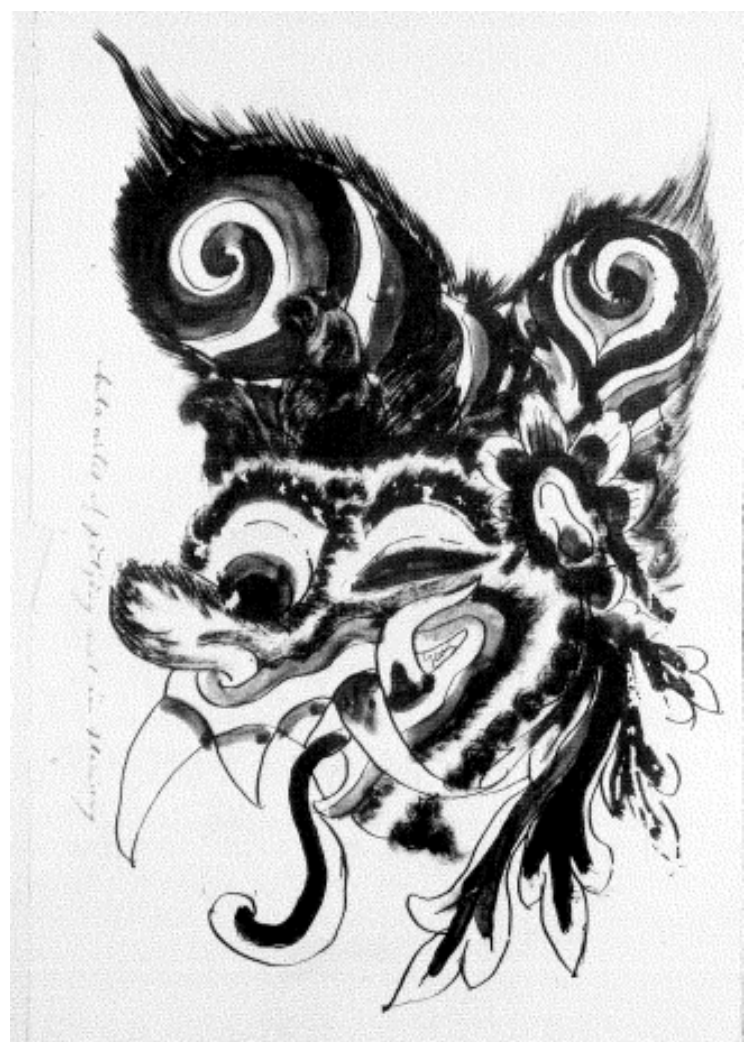

Figure 4: Ornament art is usually very decorative, made more spontaneous and expressive Source: Hinzler, 1987.

The adaptation of modern art practices carried out by the North Balinese artists was not only done in their paintings, but was also shown in their shadow puppet performances. The puppeteer Banjar named Ida Putu Sweca (1898), made a bondresan or funny puppet figure out of existing classic puppet characters (Hinzler: 2013: 18). In terms of form, it does not follow the form of puppets in general, but more on personal creations with forms leaning towards cartoons. The puppet forms in the form of funny figures or servants are usually called punakawan. The shape of his creation is an imaginative form with a human-shaped horse head wearing full clothing and shoes. His creation was named Gede Baag (see Figure 5). 


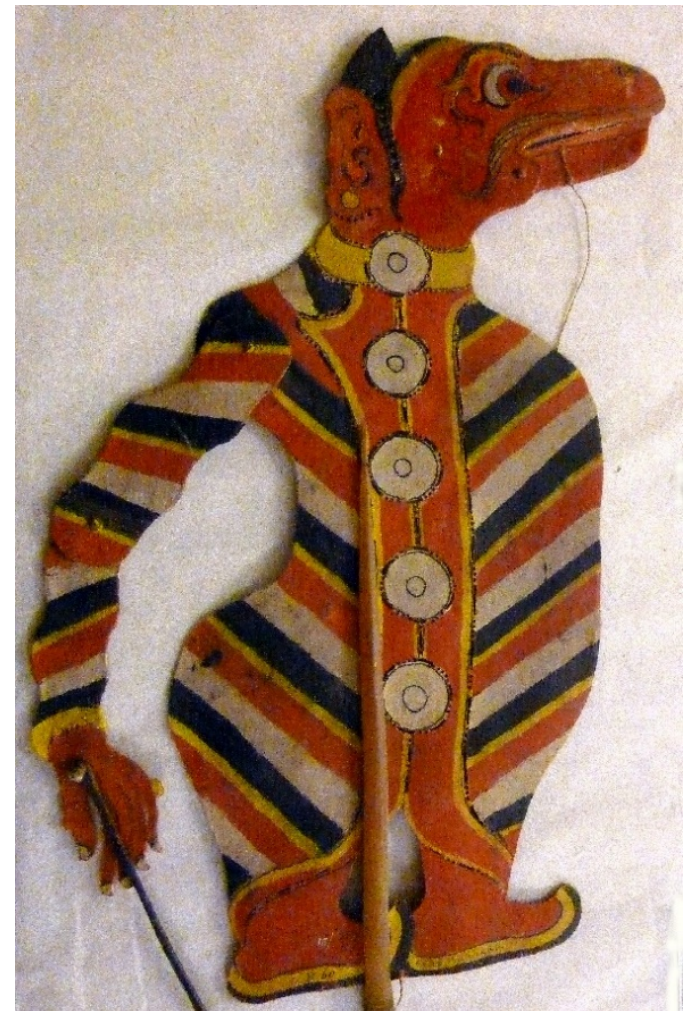

Figure 5: New cartoon figure (bondres) in puppet performance. Source: Hinzler, 2013.

\section{DISCUSSION}

The early signs of modern art displayed in traditional wayang paintings in North Bali were due to the role of these two Europeans and the intervention of the Dutch government which had a significant impact on the traditional arts. North Bali, which is also considered a marginal area, is more open and egalitarian, in contrast to South Bali which is more inland and feudal in nature. North Balinese people are more open, adaptable, creative and accepting of new things that they think are good (Vicker, 2009: $5)$.

The process of forming traditional Balinese puppet painting was done through a process that lasted for centuries by way of various outside cultural influences and acculturation to produce a pakem, standard or a common convention. Thus, traditional painting can be understood as having different collective elements from individual modern art. The aesthetic diversity of traditional art is influenced by the dominance of Hindu-Javanese cultural elements that came by through the conquest of the kingdoms in Bali. Likewise, Chinese culture can once in a while be seen complementing the aesthetics, and in the techniques and media used. The introduction to elements of Chinese culture in Balinese society was made through trade, with evidence of the use of uang kepeng as a symbol in transactions, which was also used in ceremonies.

Visual changes from Balinese traditional puppet art to modern painting are marked by these subtle signs. Puppet painting still shows a still strong decorative aspect or puppet style. The 'modernization' is limited to the technique and the use of its media. As such, it can be said that modern art has not yet changed the understanding and the artistic approach of the artists as a whole, though traces of these transfers of modern knowledge could only be seen as discussed in this paper. Nevertheless, the knowledge transfer has at least changed the perspective of the people or artists of North Bali.

The painters can be seen as imitating the use of techniques and methods of drawing by European academics, but it must be argued that Balinese artists are more likely to use imaginative processes which 
resulted in a style that is not in accordance with what is prevailing in the West. They rely more on intuition rather than mathematical, scientific-analytic calculations, as do most European painters.

In terms of realistic and anatomical understanding, Balinese artists do not fully follow modern norms. Instead, they continue to follow the prevalent style of painting puppet characters. To illustrate, the face is stretched to elicit three quarters, the legs are depicted to appear from the front, and certain parts of the anatomy are made based on estimated calculations. Lighting, if any, is not based on reality like impressionist paintings, but it is instead based on their imagination. The paintings still emphasize flatness or plane and do not show depth. They draw humans based on what they can memorize and mostly based on stereotypical forms (Djelantik, 1990: 120).

The introduction of modern art by Van der Tuuk and WOJ. Nieuwenkamp to Balinese artists was not done by way of direct intervention as in through a formal education. Balinese artists were free to make art according to instructions given by Van der Tuuk, following the entry of his dictionary. The function of traditional art which was for the sake of religious ceremonies was shifted towards the profane. It has gone from the function of sacred art to more pragmatic art, i.e., art for the special purposes of the dictionary and as a practical information medium. Besides that, commodity practices emerged, and in turn, Balinese traditional art was slowly being sold as products that were exhibited abroad and were also collected.

\section{CONCLUSION}

The initial emergence of paintings with new features in North Balinese society could not be separated from external factors due to the influence of two European scientists and the intervention of the colonial government. The interactions of the Europeans and the community that taught directly or indirectly, led to changes and new values in the arts. The active role of the Balinese artists in responding to the influence of modern art accelerated the influence of this process of change. The adaptation and change in the transfer of knowledge in practice and ideology resulted in a unique style of traditional painting. Although Balinese artists have used the media and modern techniques, their understanding of modern art is very limited so that shows that they are still producing works that visually adhere to traditional puppet figures.

Balinese traditional painting has since then adopted and adapted new modern forms introduced by Europeans. The paintings became innovations or imaginative creations in comparison to the previous tradition, which still retains its decorative properties. The initial change in painting during the 1870s was a unique and sudden adaptation of the creativity and the strength of the traditions of Balinese artists, who were confronted by the rules of modern art from Western painters and scientists who came to Bali.

Although these "modern" elements were introduced, North Bali at that time could not be said to be "modern", only showing "modern phenomena" because the traditional visual tendencies were still very thick, and thus had not yet shown a striking change. The decorative style of puppets still appears; the changes made by Balinese artists were limited to experimentation, in understanding the new media and techniques known at that time.

The process of art from communal or collective practices to individual practices is not yet fully developed. Nevertheless, as discussed in this paper, signs of paintings moving from what is intended for the sake of sincere (yadnya) to accompany religious ceremonies, has moved towards the direction of the profane, which has a more economic nature or could be seen as a commodity for the benefit of the other. 


\section{ACKNOWLEDGEMENTS}

The authors thank Prof. H.I.R. Hinzler from the Leiden University in the Netherlands who has given two Van der Tuuk catalogue e-books about traditional Balinese paintings and shadow puppets. The authors also thank the Museum Buleleng in the city of Singaraja for providing information related to historical data on the development of North Balinese art. the LPPM Telkom University Institute which has funded this study as basic and applied research.

\section{REFERENCES}

Adnyana, Wayan.2018. Pita Maha Social Movement of Balinese Painting in the 1930s. KPG Gramedia Jakarta, Indonesia.

Ardika, I Wayan. Parimartha, I Gede. Wirawan, A A Bagus. 2015. The History of Bali, from Prehistoric to Modern. Udayana University press. Bali Indonesia.

Burham, M. Agus.2013. The Birth of the Ubud Style and Batuan Style in Balinese Painting, during the Dutch Colonial Period. Journal of Dimensions, Vol.10-No.1. February 2013.

Djelantik, A.A.M. 1990. Balinese Paintings. Singapore: Oxford University Press.

Hinzler, H.I.R, 2013, North Bali First Encounters, Innovations in North Bali, Influences from Abroad \& Influences of North Bali Abroad. End 19th-Beginning 20th-Century (Paper to Presented in the Buleleng Museum, Northern Bali.

Hinzler, H.I.R. 1986. Catalog of Balinese Manuscripts. Volume II Descriptions of the Balinese Drawing from the Van der Tuuk Collection. E.J. BRILL / LEIDEN University Press Leiden. Hinzler, H.I.R. 1987. Catalog of Balinese Manuscripts. Part I. Reproduction of the Balinese Drawing from the Van der Tuuk Collection. E.J. BRILL / LEIDEN University Press Leiden.

Lombard, Denys. 1996. Cross Culture Nusa Java, Westernized Limits, Gramedia Pustaka, Jakarta.

Neka, Suteja. Kam, Garrett. 1990. The Development of Painting in Bali. Selection from the Neka Art Museum. Neka Dharma Foundation. Ubud Bali Art Museum. Indonesia.

Putra, I Dewa Alit Dwija. 2019. Tracing the classic Balinese Wayang Way. Jurnal Rupa, [S.I.], V.3, n 2, p 130-149, sep. 2019.ISSN 2503-1066.

Ratna, Nyoman Kutha. 2016. Research Methodology Cultural Studies and Social Sciences Humanities in General. Student Library (Matter II) Yogaykarta.

Sudarta, GM. 1975. Balinese Painting in Three Generations. Gramedia Jakarta-Indonesia. Supangkat, Jim. 1996. Multiculturalism / Multi Modernism, Journal of Kalam Edition: 8 ,

Jakarta. 1996.

Vicker, Adrian. 1989. Bali A Paradise Created. Reprinted by Periplus Editions (HK) Ldt. Vicker, Adrian. 2009. Coastal Civilization, Towards Southeast Asian Cultural History, Larasan

Library. Denpasar Bali.

Vicker, Adrian.2012. Balinese Art Painting and Drawing of 1800-2010. Published by Tuttle Publishing, an imprint of Periplus Edition (HK) Ltd.

Vickers, Adrian. 2011. Balinese Art versus Global Art. Journal of Bali Studies. Volume 01, Number 02, October.

Warsika, I Gusti Made. 2017. Ancient Bali, The Collapse of the Majapahit Kingdom and Its Influence on Bali. Pustaka Bali Post, Denpasar Bali Indonesia. 